\title{
Houd afstand
}

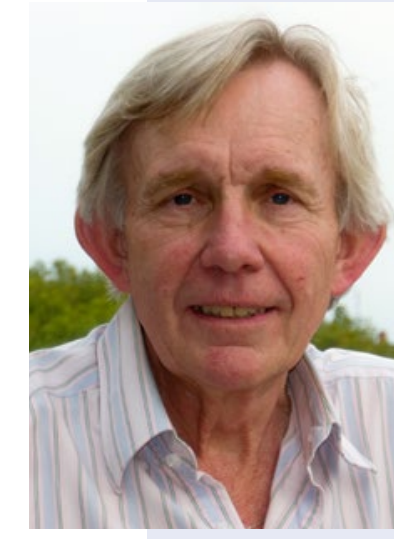

Wim Otto

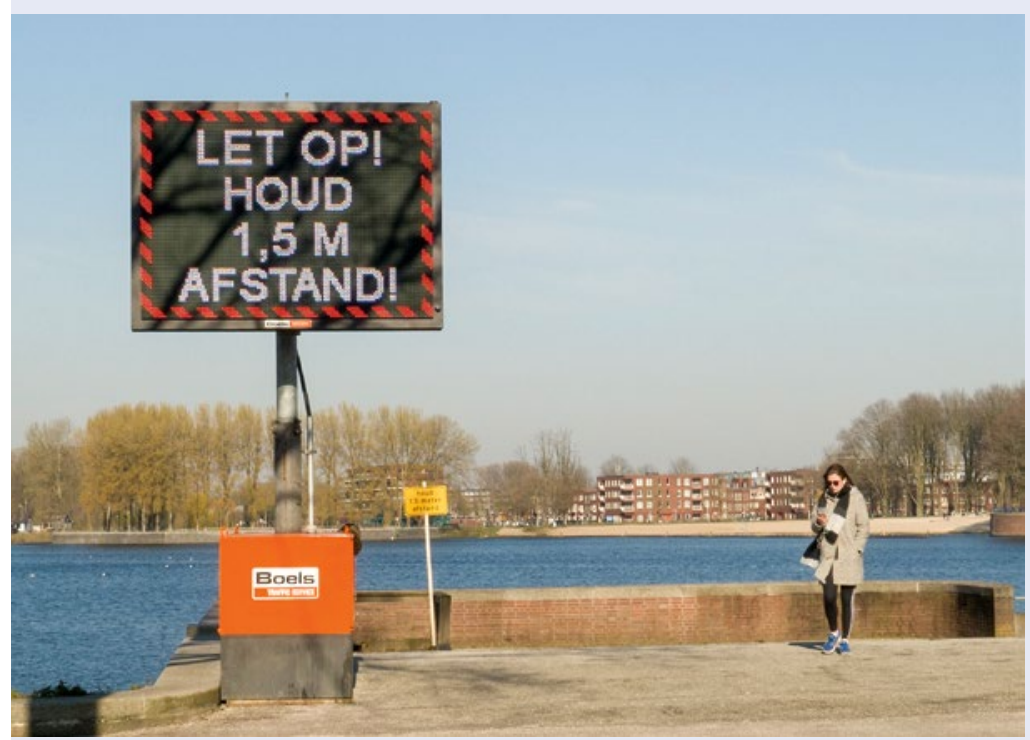

Greijn e.a. beschrijven in hun artikel Aios in coronatijd aan de hand van de resultaten van zelfstudieopdrachten hoe aios verzekeringsgeneeskunde beoordelen-op-afstand hebben ervaren.

Naarmate de crisis langer duurt, wordt meer en meer geklaagd over de onduidelijkheid van het beleid. Maar wat is er onduidelijk, vraag ik mij af. Tussen de regels door hoor ik dat mensen het niet eens zijn met het beleid en moeite hebben met de voortdurende onzekerheid. We zien dit fenomeen terug bij de aios: er is behoefte aan een eenduidig advies van de beroepsverenigingen. Waren de verschillen dan zo groot? Of moeten we concluderen dat duidelijkheid geen remedie is tegen onzekerheid? Des te belangrijker is het dat professionals zich gesteund voelen door hun omgeving, dat er vertrouwen is in hun deskundigheid, zoals één van de aios naar voren bracht. En dat er dus ook voldoende ruimte is om te kunnen concluderen dat een oordeel níet mogelijk is. Want niet alleen de maatschappelijke constellatie waarin wij tijdens deze crisis ons werk moeten doen brengt onzekerheid met zich mee, ons 'oordelen in onzekerheid' heeft er een extra dimensie bijgekregen. Je ziet niet wie er voor je zit, maar ook: het bespreken van beladen onderwerpen is moeilijker door de telefoon.

TBV is zelf ook op pad gegaan voor een eerste inventarisatie van de ervaringen met het telefonisch spreekuur. We hebben een vifftal collega's geïnterviewd, van wie één uit België, een mix van bedrijfs- en verzekeringsartsen, man en vrouw, met veel ervaring of nog aan het begin van hun carrière. We hebben steeds zo veel mogelijk dezelfde vragen gesteld, zodat we ons een beeld kunnen vormen van de overeenkomsten en de verschillen.

Uit de interviews komt het telefonische consult naar voren als een efficiënte en effectieve vorm van vooronderzoek: soms kan de voorliggende vraag worden beantwoord en zo niet, dan kun je inschatten wanneer het beste moment is voor nader onderzoek en de cliënt eventueel wat 'huiswerk' meegeven.

Dat het telefonisch spreekuur - of het videoconsult - het fysieke spreekuur in de meeste gevallen zou kunnen vervangen is niet het beeld dat uit de interviews opdoemt. Er valt wel een aardig lijstje met criteria uit af te leiden 


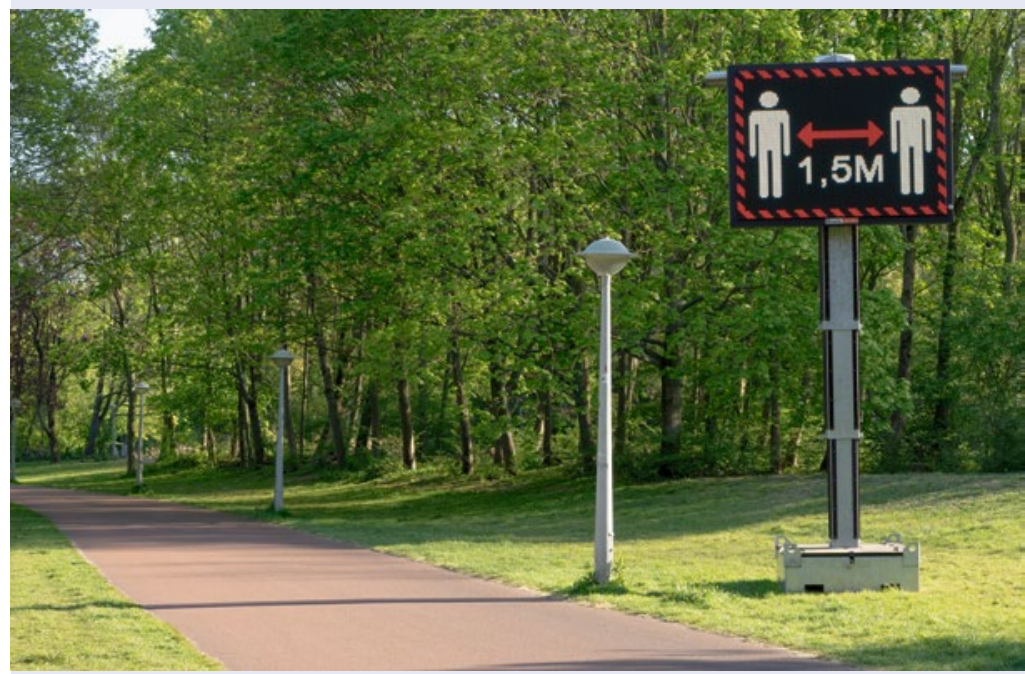

op grond waarvan de kans om tot een afgerond oordeel te komen kan worden ingeschat:

- als je iemand al vaker hebt gezien of iemand is van eerdere contacten bekend, kun je makkelijker tot een oordeel komen;

- hoe meer informatie er al is over de cliënt, des te minder onzekerheid over het oordeel;

- bij verschil van mening met de cliënt over de belastbaarheid zal een contact op afstand niet door de cliënt worden geaccepteerd;

- bij elkaar tegensprekende beoordelingen in het verleden zal een conclusie zonder fysiek spreekuur weinig overtuigend kunnen zijn voor de cliënt dan wel onzekerheid bij de arts zelf niet voldoende kunnen wegnemen;

- als er op voorhand al sterke aanwijzingen zijn dat lichamelijk onderzoek nodig is om tot een goed oordeel te komen kan beter meteen een fysiek onderzoek worden gepland, tenzij een telefonisch consult als vooronderzoek toegevoegde waarde kan hebben;

- hoe meer belastend een fysiek onderzoek is voor de cliënt (bijvoorbeeld als cliënt ver weg woont) des te kritischer de noodzaak daartoe in ogenschouw moet worden genomen.

Een belangrijke vraag is in hoeverre het 'comfort' van de dokter een rol mag spelen. Zoals een van de collega's het formuleerde: je mist de non-verbale signalen dus ga je je extra inspannen om te luisteren. Je moet er meer effort in steken om eruit te halen wat je wilt. Ofwel: je kunt je afvragen of een telefonisch spreekuur wel efficiënter is - met zo min mogelijk inspanning het vereiste resultaat verkrijgen. Die vraag is des te prangender nu veel collega's toch de ervaring hebben dat het spreekuur zelf er niet korter op wordt. De tijdswinst zit hem vooral in reistijd, de 'rituelen' bij de receptie, de wachtkamer, en dergelijke. Maar het comfort van de dokter wordt in niet geringe mate ook bepaald door de volledigheid van de beoordeling en daarmee door de zekerheid van het oordeel.

Houd afstand blijft voorlopig nog wel het devies, maar voorbij de anderhalve meter is een genuanceerdere benadering niet alleen toegestaan maar ook vereist.

Als die anderhalve meter in werksituaties kan worden gehandhaafd, kan iedereen dan gewoon aan het werk? En wat als de kwetsbare werknemer het zelf niet vertrouwt? Hoe zwaar weegt dan de misschien geringe kans om ziek te worden in verhouding tot de soms zeer ernstige gevolgen van COVID-19? Oude dilemma's in een nieuwe (corona)jas, waarbij ook de achterliggende vraag weer volop voor het voetlicht komt: is er wel sprake van arbeidsongeschiktheid zolang er nog geen sprake is van ziekte (lees: COVID-19). Die discussie woedt nog in alle hevigheid, waarbij meer en minder opportunistische opvattingen worden geventileerd. Maar is er wel ruimte voor al die opvattingen? Het mooie van het artikel van Weel et al. is dat zij laten zien dat je door consequent toepassen van de methode morele oordeelsvorming tot een evenwichtig advies over werkhervatting kunt komen. Waarbij alle belangen èn kwetsbaarheden worden meegewogen. 